\title{
IMPROVING STUDENTS' ABILITY IN EXPRESSING IDEAS IN DESCRIPTIVE WRITING BY USING PICTURE SERIES TECHNIQUE (A Quasi - Experimental Research at SMPN 14 Bengkulu City)
}

\author{
Leny Susiana \\ University of Bengkulu \\ Email : lenysusiana86@gmail.com
}

\begin{abstract}
This research investigated the effect of picture series technique to develop the students' ability in expressing ideas in descriptive writing. It was a quasi-experimental research that involved two classes of samples, they are experimental class and control class. The population consisted of the second year students' of Junior High School Number 14 Bengkulu in Academic Year 2008/2009. The experimental class was treated by picture series technique for one month, while the control class was taught by using the conventional technique. Both classes were given pre test before treatment. The average score of both classes were analyzed by using the $t$-test formula. T count was smaller than $t$ table $(0.126<2.000)$. It means that there was no significance difference between the experimental and the control class. In other words, those classes could be accepted as the samples for this research. Both classes were given a post test after them giving a treatment (by using picture series technique) for several times. The average scores both classes were calculated by using the t-test formula. T obtained was higher than t-table (4.054>2.000). The result showed that there was a significant difference in post test score average between the experimental class and the control class. It means that picture series technique could improve the Junior High School Students' ability in expressing ideas in descriptive writing.
\end{abstract}

Keywords: Picture Series Technique, Quasi-Experimental Research, Junior High School Students'.

Abstrak: Penelitian ini menemukan efek dari tehnik gambar berseri untuk meningkatkan kemampuan siswa dalam menekspresikan ide pada tulisan deskriptif. Penelitian ini adalah penelitian kuasi eksperimental yang terbagi menjadi dua kelas, yakni kelas eksperimen dan kelas kontrol. Populasi pada penelitian ini adalah siswa kelas dua pada SMP Negeri 14 Kota Bengkulu tahun ajaran 2008/2009. Kelas eksperimen diajarkan dengan tehnik gambar berseri selama satu bulan, sementara kelas kontrol diajarkan menggunakan teknik konvensional. Kedua kelas diberikan tes awal sebelum penelitan. Nilai rata-rata dari kedua kelas di analisi menggunakan formula t-test. Nilai t-hitung lebih kecil dari nilai t-tabel (0.126<2.000). Itu berarti tidak ada perbedaan signifikan diantara kelas eksperimen dan kelas kontrol. Dengan kata lain, kelas tersebut bisa diterima sebagai sample didalam penelitian ini. Kedua kelas diberikan tes akhir setelah kedua kelas diberikan treatment (menggunakan tehnik gambar berseri) selama beberapa waktu. Nilai t-hitung lebih besar daripada nilai t-tabel (4.054>2.000). hasil ini menunjukan bahwa ada perbedaan signifikan pada nilai tes akhir dianatara kelas eksperimen dan kelas kontrol. Ini berarti bahwa tehnik gambar berseri dapat meningkatkan kemampuan siswa Sekolah Menengah Pertama dalam mengekspresikan ide pada tulisan deskriptif. 


\section{Kata Kunci: Gambar Berseri, Penelitian kuasi eksperimental, Kemampuan Siswa Sekolah Menegah Pertama.}

\section{INTRODUCTION}

Writing is a way of making meaning of our experiences, ideas and feeling in written form, and writing is taught to enable the students to use English in oral form as well.

Writing is an important skill to help students in learning. This skill has greater formality than the other skills in English. This is caused by many reasons.

Firstly, writing reinforces grammatical structures, idioms, and vocabulary.

Secondly, when the students write, they have chance to develop their knowledge because when they write, they will learn many things, such as the rules of writing itself, the arrangement of words, and sentences.

Thirdly, when the students write, they need new language, the maximum effort to express the ideas, and the constant use of eyes, hand, and brain.

In Junior High School, the students will get the lesson about the descriptive writing.

The students always get trouble in descriptive writing because they have less knowledge on the way and technique of writing.

People believe that writing is difficult activity (Langan, 1981). Sometimes they have ideas in their mind but do not know how to express it on piece of paper.

Mc Mahan and Day (1980) say that people feel difficulties to express themselves in writing. More ever Langan (1981) also states that it is difficult to transfer thoughts and feeling from one's head into a sheet paper. They also have difficulties in developing ideas in grammatical rule and developing written material in correct order.

Jordan (1997) in Atika (2006) says that, in academic writing grammatical features constantly difficulties for the student. They also have difficulties in starting writing. The student has trouble at the time getting started with their writing (Langan, 1981). Sometimes the students have different marks in the test of descriptive writing when they use visual aid and without visual aid.

For that reasons, it is important to give the solution for the students to help them in expressing their ideas into a paragraph. In this fact, the function of the picture very needed to improve the student's interest and growing to the student's motivation.

Visual aid which is usually used by the teacher to help explain the lesson is a picture. It is expected improve that condition and minimalism the students' difficulties in expressing their ideas in writing.

If the student have interest on their activities, they will enjoy in teaching learning process and they will understand the material that given by the teacher (Penny, 1998).

Picture series as one learning facility in writing can help the students to express their idea into a good composition in writing. So, in this research, the researcher only focused on the uses of the picture 
series as a visual aid to know the student's skill in expressing the idea in descriptive writing. By using picture series in a descriptive writing the students are challenged to give comment, ideas, arguments, and description of the pictures.

Picture series are valuable teaching aids in motivating students to start their writing. By giving the picture series, the students will be active and prepare their vocabulary spontaneously in their minds and will expressed when they start to write. Therefore, this study was guided by a research question: "Can picture series improve Junior High School Students' ability in expression ideas in descriptive writing?"

\section{METHODOLOGY OF RESEARCH}

This research was a quasi-experimental study which consisted of two classes from the same qualification and academic background. They are the experimental and the control class. The experimental class was class which given a treatment using pictures series, while control class was taught by using regular techniques or using the conventional treatment. The samples of this study were VIII E and VIII F class of SMPN 14 Kota Bengkulu.

Writing test was the instrument that used in this study to know the students' ability in writing descriptive before and after the treatment using Picture Series. Thus, independent sample t-test was run to find out the difference of students' score on pre-and post test both experiment and control class.

\section{RESULT AND DISCUSSION}

The result of pre test was to get the mean score from both classes and from two correctors that could be seen in the table below:

Table 1: The Pre Test Result

\begin{tabular}{|c|c|c|}
\hline \multirow{2}{*}{ Score } & \multicolumn{2}{|c|}{ Class } \\
\cline { 2 - 4 } & Control & 67 \\
\hline Higher & 62.5 & 36.5 \\
\hline Lower & 33 & 1926.5 \\
\hline Total & 1964.5 & 48.16 \\
\hline Mean & 47.91 & 1.29 \\
\hline F count & & 1.88 \\
\hline F table & \multicolumn{2}{|}{} \\
\hline T count & \multicolumn{2}{|c|}{0.126} \\
\hline T table & \multicolumn{2}{|c|}{2.000} \\
\hline
\end{tabular}


The result of the pre test was calculated by using the formula of $F$ value. From the $F$ value calculation, the F obtained was 1.29 , and the $\mathrm{F}$ table was 1.8752 . It means that $\mathrm{F}$ obtained was smaller than F table $(1.29<$ 1.8752). From the result, both samples had equal variances.

From the t-test calculation, the $\mathrm{t}$ obtained was 0.126. And t table was 2.000. It means that $\mathrm{t}$ obtained was smaller than $\mathrm{t}$ table $(0.126<2.000)$. Briefly, these two classes had similar ability and it means that those two classes can be accepted as the samples in the study.

The conclusion from the result, $\mathrm{H}_{\mathrm{o}}$ was accepted and $\mathrm{H}_{\mathrm{i}}$ was rejected. In other words there was no significant difference in pre test score average between the experimental class and the control class. It means that both groups had equal ability. This experiment could therefore be continued.

The result of post test was to get the total score and mean score from both the classes that could be seen in the table below:

Table 2: The Post Test Result

\begin{tabular}{|c|c|c|}
\hline Score & \multicolumn{2}{|c|}{ Class } \\
\hline & Control & Experimental \\
\hline Higher & 75 & 50.5 \\
\hline Lower & 41 & 2622.5 \\
\hline Total & 2350.5 & 65.56 \\
\hline Mean & 57.33 & 1.35 \\
\hline F count & & 1.88 \\
\hline F table & \multicolumn{2}{|}{} \\
\hline T count & \multicolumn{2}{|}{} \\
\hline T table & \multicolumn{2}{|c|}{} \\
\hline
\end{tabular}

Based on the table above could be seen that the mean score was 65.56 , the highest score was 82.5 , and the lowest score was 50 in the experimental class, while it was 57.33, the highest score was 75, and the lowest score was 41 in control class.

The result of the post test was calculated by using the formula of $\mathrm{F}$ value. From the $\mathrm{F}$ value calculation, the $\mathrm{F}$ obtained was 1.35 and the $F$ table was 1.88 . It means that $\mathrm{F}$ obtained was smaller than $\mathrm{F}$ table $(1.35<1.88)$. In other words, both samples had equal variances. Thus, analysis was continued by using the t-test for equal 
variances.

From the t-test calculation, the obtained was 4.054 and t table was 2.000. It shows that $\mathrm{t}$ obtained was bigger than $\mathrm{t}$ table (4.054>2.000). It could be concluded that the alternative hypotheses $\left(\mathrm{H}_{\mathrm{i}}\right)$ was accepted or there was significant positive effect of treatment for experimental class. In other words, the treatment using picture series technique was successful.

This research showed that used the picture series technique in teaching writing could help the students to develop their ideas. There are some techniques which could give motivation to the students in writing. For example Hati (2000) used sentence rearrangement activity to improve the students' achievement in writing a short paragraph. Another technique used writing diary to increase students' writing skill (Hartati, 2000). Nababan (2007) used journal writing to improve students' achievement in writing skill and this technique was effective in improving writing skill.

Other researcher also did research in writing, Boerhan (2006), she found out the effect of composition revision to the students' writing achievement and she concluded that composition revision was effective in writing skill.

While in this research the researcher used picture series technique to improve students' ability in expressing their ideas in descriptive writing. Picture was a kind of visual material that could express the idea or information in concrete way (Raimes, 1983).
According to Adam (1990), in Hati (2000), pictures were prominent feature of children textbooks;

1) Picture may provide clues to identify words that are otherwise had to recognize and

2) Picture may stimulate interest in reading-writing and promote a better understanding of the information.

Based on the result of pre test and post test in the previous chapter, it was found that the pictures series technique could improve the students' ability in expressing ideas in descriptive writing. In the experimental class showed that their mean score increased bigger than the control class in result post test $(48.16>65.56)$.

Furthermore, from the t-test calculation, $t$ obtained was compared to the value of $t$ table. It showed that $t$ obtained was higher than t table $(4.054>2.000)$. Gay (1990) stated that if t obtained was higher than $\mathrm{t}$ table, it means that the result of research was successful, and it proved that the treatment was successful. In other word, the alternative hypothesis was accepted.

Based on the explanation above, it is hoped to the teacher may use the picture series technique to improve students' ability in writing because teaching writing by using visual aids can make the students easily. The students will be assisted in expressing their ideas when they write by using media. 


\section{CONCLUSION}

By using the formula of $t$-test calculation, $t$ obtained was higher than $t$ table (4.054>2.000). It could be concluded that $\mathrm{H}_{\mathrm{i}}$ (alternative hypothesis) was accepted and $\mathrm{H}_{0}$ is rejected.

From the result the researcher concluded that the treatment (picture series) could be used as one technique to improve students' ability in expressing ideas in descriptive writing at the second year of SMPN 14 Bengkulu.

To suggest, further research is highly recommended to find the other techniques in designing the material for students. It is highly recommended to do the same research on the other population or in different education levels example at the Senior high School or the Vocational School.

\section{REFERENCES}

Ali, Mohammad, H. 1993. Strategi penelitian pendidikan. Bandung: Angkasa.

Arikunto, Suharsimi. 1998. Prosedur penelitian: suatu pendekatan praktek. Jakarta: Rineka Cipta.

Atika, Ria. 2006. The Student's writing skill of descriptive text (The study at the third year students of SMAN 3 BKL). The University of Bengkulu: Unpublished paper.

Hati, Impian. 2001. The effect of sentences rearrangement activity in English teaching process toward the students' achievement in writing a short paragraph. The University of Bengkulu: Unpublished paper.

Hartati. 2000. The effect of writing diary toward students' writing skill. The University of Bengkulu: Unpublished paper.

Langan, John. 1984. College writing skills. USA: MC GRAW-Hill. Inc.

Mc. Mahan, and Day. 1980. The writer's rhetoric and handbook. New York: Mc. Graw-Hill, inc.

Nababan, Sally. 2007. The effect of joumal writing to the students' writing achievement. The University of Bengkulu: Unpublished paper.

Ur, Penny. 1996. A course in language teaching practice and theory. Cambridge: Cambridge University Press. 